\title{
COMMENT
}

\section{AFFORDABLE HOUSING OPTIONS UNDER PENNSYLVANIA'S THREE LEGISLATIVE REGIMES}

\author{
Clayton H. Collins ${ }^{*}$
}

\section{A Brief History of Land-Use Regulation}

\section{A. Growth Management Powers Generally}

The police power of a state includes the authority of its local governments to protect the health, morals, and safety of the communities they govern. ${ }^{1}$ Managing the growth of a community through the placement and timing of private development has repeatedly been found a valid exercise of this police power. ${ }^{2}$ As stated by the United States Supreme Court in Hadacheck v. Sebastian:

* J.D. candidate, University of Pittsburgh School of Law, 2010; M.A., University of Florida, 2007; B.S., University of Florida, 2003.

1. See Mugler v. Kansas, 123 U.S. 623, 668-69 (1887).

2. See Reinman v. Little Rock, 237 U.S. 171, 176-77 (1915) (upholding a municipal ordinance declaring that, in particular circumstances and particular localities, a livery stable, which is not a nuisance per se, shall be deemed a nuisance in fact and in law, and holding that the only limitation upon the power was that it could not be exerted arbitrarily or with unjust discrimination); Hadacheck v. Sebastian, 239 U.S. 394, 412 (1915) (upholding a municipal ordinance prohibiting the construction of a brick-kiln within the city limits of Los Angeles); Vill. of Euclid, Ohio v. Ambler Realty Co., 272 U.S. 365, 397 (1926) (upholding a municipal zoning ordinance as a valid exercise of the police power against a constitutional challenge); Tahoe-Sierra Pres. Council, Inc. v. Tahoe Reg'l Plan. Agency, 535 U.S. 302, 343 (2002) (upholding a temporary moratorium on the development of private property surrounding Lake Tahoe as a valid exercise of police power). 
It is to be remembered that we are dealing with one of the most essential powers of government, one that is the least limitable. It may, indeed, seem harsh in its exercise, usually is on some individual, but the imperative necessity for its existence precludes any limitation upon it when not exerted arbitrarily. A vested interest cannot be asserted against it because of conditions once obtaining. . . . To so hold would preclude development and fix a city forever in its primitive conditions. There must be progress, and if in its march private interests are in the way, they must yield to the good of the community. The logical result of petitioner's contention would seem to be that a city could not be formed or enlarged against the resistance of an occupant of the ground, and that if it grows at all it can only grow as the environment of the occupations that are usually banished to the purlieus. ${ }^{3}$

Modern growth management, as implemented through land use controls, has been left solely to state governments. ${ }^{4}$ The federal government's most recent foray into this area of regulation was heavily criticized and pejoratively labeled "federal zoning." The federal government, however, continues to exert some influence over the control of land uses through its Consolidated Plan requirements. ${ }^{6}$ Two key tools comprise virtually all modern growth management strategies implemented by local governments: comprehensive planning and comprehensive zoning. ${ }^{7}$ These two related but distinct growth management devices have caused much confusion for local governments. ${ }^{8}$

Modern-day comprehensive planning arose in part from public movements to sanitize and beautify cities that were both unhealthy and unsightly as a result of America's rapid industrialization. ${ }^{9}$ The notion of comprehensive planning, however, has its roots in colonial America. ${ }^{10}$ The most notable and influential plan of the colonial era was the plan for the new

3. Hadacheck, 239 U.S. at 410. See also Pa. Coal Co. v. Mahon, 260 U.S. 393, 413 (1922) (upholding the proposition that " $[\mathrm{g}]$ overnment hardly could go on if to some extent values incident to property could not be diminished without paying for every such change in the general law. As long recognized some values are enjoyed under an implied limitation and must yield to the police power.”).

4. See John R. Nolon, Champions of Change: Reinventing Democracy Through Land Law Reform, 30 Harv. Envtl. L. Rev. 1, 20-21 (2006) (describing the national Land Use Policy and Planning Assistance Act in the 1970s).

5. $I d$.

6. The Consolidated Plan requires local governments seeking federal funds for certain programs to perform an analysis of the local housing market, examination of barriers to affordable housing, and the development of strategies for the creation of affordable housing. 24 C.F.R. $\S \S 91.210-.220$ (2010).

7. Julian C. Juergensmeyer \& Thomas E. Roberts, Land Use Planning and Development Regulation LaW $\S \S 2.6-7$, at 22-24 (2003).

8. Id. $\S \S 2.7,2.13$, at 23, 34-35. California, Delaware, Florida, Kentucky, Maine, Nebraska, Nevada, New Jersey, Oregon, South Dakota, and Vermont have prevented this confusion by defining the separateness of these documents by either court decision or by statute. See Edward J. Sullivan \& Thomas G. Pelham, Comprehensive Planning and Growth Management, 28 URB. Law. 819 passim (1996).

9. JuergenSMEyer \& Roberts, supra note 7, at 17-20.

10. Id. at 17 . 
City of Philadelphia. ${ }^{11}$ The origin of comprehensive zoning by local governments is also traceable to colonial America. ${ }^{12}$ The first comprehensive zoning ordinance was adopted by New York City. Four years after its adoption, the ordinance was upheld "as a proper exercise of the police power" by the Court of Appeals of New York. ${ }^{13}$

\section{Comprehensive Planning Components}

The comprehensive plan "serves as an overall set of goals, objectives, and policies to guide" the local legislative body in its decision making in regard to the physical development of the community. ${ }^{14}$ Such plans often serve as the "rational basis" upon which comprehensive zoning decisions are grounded. ${ }^{15}$ Depending upon the particular requirements of a jurisdiction, a comprehensive plan may or may not be adopted as law by the local government. The State of Florida, for instance, enacted the Local Government Comprehensive Planning and Land Development Act of 1985 (codified at Chapter 163, Florida Statutes). It requires local governments to adopt and amend existing plans for consistency with the State and Regional plans. Failure to do so will result in loss of state revenue-sharing to local governments and loss of grant money controlled by the state government. ${ }^{16}$ Pennsylvania recently moved in a similar direction by amending its growth management legislation to require "state agencies to consider and rely upon comprehensive plans . . . when making infrastructure decisions that impact land use." ${ }^{17}$ The four defining components of a comprehensive plan include its future-orientation, its continuity, its basis upon present and projected conditions, and its focus on equity. ${ }^{18}$

11. Principles and Practice of Urban Planning 9-10 (William I. Goodman \& Eric C. Freund eds., 4th ed. 1968) [hereinafter Urban Planning].

12. Tahoe-Sierra Pres. Council, 535 U.S. at 352 (2002) (Rehnquist, C.J., dissenting).

13. Lincoln Trust Co. v. Williams Bldg. Corp., 128 N.E. 209, 210 (N.Y. 1920).

14. Urban Planning, supra note 11 , at 349 .

15. Juergensmeyer \& Roberts, supra note 7, at 27.

16. Roy R. Carriker, Comprehensive Planning For Growth Management in Florida (Univ. of Fla. Food \& Econ. Dep't, EDIS Document No. FE642, 2006), http://edis.ifas.ufl.edu/pdffiles/ FE/FE64200.pdf.

17. Pa. Dept. of Cmty. \& Econ. Dev., The Comprehensive Plan in Pennsylvania, Governor's Center for Local Government Services 6 (7th ed. 2001), available at http:// www.newpa.com/get-local-gov-support/publications/download.aspx?id=342 [hereinafter PENNSYLVANIA Comprehensive Plan].

18. JUERGENSMEYER \& ROBERTS, supra note 7, at 28. 


\section{Current Role of Comprehensive Planning}

The majority of states do not mandate the adoption of comprehensive plans by local governments. ${ }^{19}$ The non-regulatory status of comprehensive planning derives mainly from the 1920s standard planning and zoning legislation promulgated by the Department of Commerce. ${ }^{20}$ As Julian Juergensmeyer and Thomas Roberts explain:

The Standard State Zoning Enabling Act required that zoning regulations and zoning decisions be made "in accordance with the comprehensive plan," but failed to address the obvious question of what a comprehensive plan was. Later, the Standard City Planning Enabling Act of 1928, while boldly setting forth the suggested "elements" of comprehensive plans, and the manner in which a city might prepare and adopt them, failed to strictly define the legal relationship between plans and zoning ordinances. In addition, plans were optional under the Standard City Planning Enabling Act. ${ }^{21}$

As most jurisdictions went no further than adopting the language of the model acts in defining the relationship between comprehensive planning and comprehensive zoning, the duty to define this relationship fell to the courts. ${ }^{22}$

\section{Comprehensive Zoning Components}

Comprehensive zoning, as contrasted with comprehensive planning, is the "division of a municipality (or other governmental unit) into districts, and the regulation within those districts of: (i) the height and bulk of building and other structures; (ii) the area of a lot which may be occupied and the size of required open spaces; (iii) the density of population; and (iv) the use of

19. Id. at $31-33$.

20. Id.

21. $I d$.

22. See Palatine Nat'l Bank v. Vill. of Barrington, 532 N.E.2d 955, 963 (Ill. App. Ct. 1988) (holding that "[o]ne of the more important factors the court considers in determining the reasonableness of a proposed [zoning change] is whether the community has given care and consideration to the use and development of the land. The existence of a comprehensive plan indicates the community has given careful consideration to the orderly utilization of the property within its borders."); Kozesnik v. Montgomery Twp., 131 A.2d 1, 7-8 (N.J. 1957) (arising prior to the enactment of N.J. Stat. Ann. § 40:55D-62 which now requires the enactment of certain elements of a formal comprehensive plan by local governments); Udell v. Haas, 235 N.E.2d 897, 900-01 (N.Y. 1968) (holding that " $[\mathrm{t}]$ he comprehensive plan is the essence of zoning. Without it, there can be no rational allocation of land use. It is the insurance that the public welfare is being served and that zoning does not become nothing more than just a Gallup poll.”). 
buildings and land for trade, industry, residence, or other purposes."23 According to Goodman and Freund:

Zoning is essentially a means of insuring that the land uses of a community are properly situated in relation to one another, providing adequate space for each type of development. It allows the control of development density in each area so that property can be adequately serviced by such governmental facilities as the street, school, recreation, and utilities systems. This directs new growth into appropriate areas and protects existing property by requiring that development afford adequate light, air and privacy for person living and working within the municipality. ${ }^{24}$

Comprehensive zoning, in its present form, became immensely popular in the first part of the 20th Century. By the time the Village of Euclid's zoning ordinance was upheld by the United States Supreme Court in $1926,{ }^{25} 564$ municipalities had enacted zoning measures. ${ }^{26}$

\section{Current Role of Comprehensive Zoning}

Comprehensive zoning remains the core tool of land-use regulation. ${ }^{27}$ While the essence of comprehensive zoning (i.e., the division of a municipality into districts) has remained fundamentally unchanged, the adoption of new control techniques within zoning regimes has significantly altered comprehensive zoning from its original form. ${ }^{28}$

Comprehensive zoning is distinguished from the exercise of other municipal powers because the zoning regulations differ from district to district. ${ }^{29}$ Building codes or sanitary regulations, in contrast, apply uniformly throughout an entire municipality. ${ }^{30}$ This distinction creates a substantial risk of arbitrary treatment toward individual property owners. ${ }^{31}$ Recognizing this threat, legislatures (through zoning enabling acts), and courts (through

23. Urban Planning, supra note 11, at 403 (referring to the definition of comprehensive zoning used by the U.S. Department of Commerce in the 1924 Standard Zoning Enabling Act, on which most current legislation is based).

24. Id.

25. Vill. of Euclid, 272 U.S. at 365.

26. JUERGENSMEYER \& ROBERTS, supra note 7, at 43.

27. Id. at 41 ; Urban Planning, supra note 11, at 403 (referring to the definition of comprehensive zoning used by the U.S. Department of Commerce in the 1924 Standard Zoning Enabling Act, on which most current legislation is based).

28. JUERGENSMEYER \& RoBERTS, supra note 7, at 41.

29. URBAN PlanNing, supra note 11, at 404 .

30. Id.

31. Id. 
common law), have developed general limitations on the exercise of zoning authority. ${ }^{32}$ These limitations include the following general requirements: (i) regulations within a district must be uniform for each class of building, (ii) there must be a reasonable basis for classifying particular areas, (iii) the ordinance must cover the entire jurisdiction of the municipality, and (iv) the regulations must be reasonable in their application to particular properties. ${ }^{33}$

\section{Consistency Between Comprehensive Planning and Comprehensive} Zoning

The confusion mentioned earlier regarding comprehensive planning and comprehensive zoning arises mainly from the adoption of comprehensive zoning regulations by municipalities that fail to also adopt comprehensive planning regulations. ${ }^{34}$ Comprehensive zoning, in theory, is intended only to be one of several administrative tools available to municipalities to carry out a comprehensive plan. ${ }^{35}$

For much of the time municipalities have been empowered to regulate land use in Pennsylvania, there was no requirement that municipalities adopt a comprehensive plan. In 2000, this began to change as amendments to Pennsylvania's enabling land-use planning legislation provided incentives for municipalities to adopt a comprehensive plan. ${ }^{36}$ Comprehensive plans continue to remain optional, however. Describing the role of the comprehensive plan in Pennsylvania in 2001, The Comprehensive Plan in Pennsylvania explains:

A municipality is not required to regulate land use, but if it decides to implement zoning, it must have a well-articulated statement of community development objectives. Objectives should be supported by sufficient analysis and documentation to defend the zoning or other land use ordinances of the community against legal challenges. Preparing a comprehensive plan provides the most effective basis for the development of land use ordinances. ${ }^{37}$

Implicit in the last sentence is the notion that there are other bases from which to defend comprehensive zoning or other land-use regulations. This statement is certainly placing the functions of the comprehensive plan and

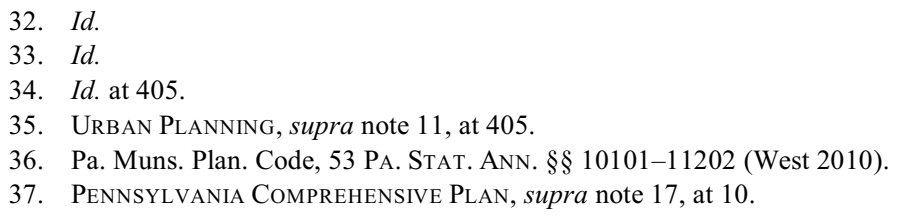


comprehensive zoning in correct relation to one another. It still, however, allows comprehensive zoning legislation to be sufficient in and of itself.

\section{Affordable Housing Generally}

\section{A. Defining Affordable Housing}

Affordable housing is defined by the U.S. Department of Housing and Urban Development as housing that costs (including rent, utilities, property taxes, and insurance) less than 30 percent of a household's total income. ${ }^{38}$ Households that pay more than this amount are considered "housing burdened," and consequently will be able to afford less of other necessities such as food, clothing, transportation, and health care..$^{39}$ Nationally, more than 12 million households pay more than 50 percent of their annual income for housing costs. ${ }^{40}$ More disturbing, perhaps, is the data showing that a family with one full-time worker earning the minimum wage cannot afford the local fair-market rent for a two-bedroom apartment anywhere in the United States. ${ }^{41}$ Two trends have effectively driven the affordable housing dilemma in the United States. First, wages and income have not kept pace with the ever increasing costs of daily living such as transportation, health insurance, child care, and housing. ${ }^{42}$ Second, the availability of affordable housing units has continually decreased. ${ }^{43}$

\section{B. The Current Housing-Wage}

To illustrate the severity of this country's affordable housing condition, commentators frequently use a number referred to as the "housing wage." 44

38. U.S. Dep't of Hous. \& Urban Dev., Affordable Housing, http://www.hud.gov/offices/cpd/ affordablehousing/index.cfm (last visited Feb. 10, 2010).

39. Id.

40. $I d$.

41. Id.

42. Karen Destorel Brown, Expanding Affordable Housing Through Exclusionary Zoning: Lessons from the Washington Metropolitan Area 1 (Brookings Inst. Ctr. on Urban \& Metro. Policy, 2001), http://www.brookings.edu/es/urban/publications/inclusionary.pdf.

43. As of 2007, there was an estimated deficit of 5.5 million affordable rental units available to Extremely Low Income households. Extremely Low Income households have an income at or below $30 \%$ of the area's median income. In 2009, this income equaled \$19,596. See NAT'L Low InCOME Hous. Coal. [NLIHC], Out of Reach 2009: Persistent Problems, New Challenges for Renters 4-5 (2009), available at http://www.nlihc.org/oor/oor2009/oor2009pub.pdf.

44. See, e.g., Barbara L. Bezdek, To Attain "The Just Rewards of So Much Struggle": Local- 
This number represents the amount of income a full-time worker must earn to secure affordable housing in the region in which she works. ${ }^{45}$ In Pennsylvania, the Fair Market Rent ${ }^{46}$ for a two-bedroom apartment is $\$ 799$ per month. ${ }^{47}$ To afford this rent, ${ }^{48}$ a household must earn $\$ 2,644$ monthly or $\$ 31,969$ annually. ${ }^{49}$ Assuming a worker works $2,080^{50}$ hours per year, the housing wage is $\$ 15.37$ per hour worked. ${ }^{51}$ A minimum-wage worker in Pennsylvania earns $\$ 7.15 .{ }^{52}$ Consequently, for a minimum-wage worker to afford the Fair Market Rent for a two-bedroom apartment in Pennsylvania, she must work 86 hours per week or be a part of a household that includes 2.1 minimum-wage workers.

In Pittsburgh, the Fair Market Rent for a two-bedroom apartment is $\$ 710$ per month. ${ }^{53}$ To afford this rent, ${ }^{54}$ a household must earn $\$ 2,367$ monthly or $\$ 28,400$ annually. ${ }^{55}$ Assuming a worker works $2,080^{56}$ hours per year, the housing wage is $\$ 13.65$ per hour worked. ${ }^{57} \mathrm{~A}$ minimum-wage worker in Pennsylvania earns $\$ 7.15 .{ }^{58}$ For a minimum-wage worker to afford the Fair Market Rental for a two-bedroom apartment, she must work 76 hours a week or be a part of a household that includes 1.9 minimum-wage workers.

Resident Equity Partnership in Urban Revitalization, 35 Hofstra L. Rev. 37, 69 n.157 (2006); John A. Powell, Opportunity-Based Housing, 12 J. Affordable Housing \& Community Dev. L. 188, 192 (2003).

45. See NLIHC, supra note 43 , at 4.

46. "FMRs are gross rent estimates. They include the shelter rent plus the cost of all tenant-paid utilities, except telephones, cable or satellite television service, and internet service. HUD sets FMRs to assure that a sufficient supply of rental housing is available to program participants. To accomplish this objective, FMRs must be both high enough to permit a selection of units and neighborhoods and low enough to serve as many low-income families as possible. The level at which FMRs are set is expressed as a percentile point within the rent distribution of standard-quality rental housing units. ... Standard-quality rental housing units have the following attributes: Occupied rental units paying cash rent; Specified renter on 10 acres or less; With full plumbing; With full kitchen; Unit more than 2 years old, and Meals not included in rent." Office of Policy Dev. \& Research, U.S. Dep't of Hous. \& Urban Dev., Fair Market Rents For The Section 8 Housing Assistance Payments Program Overview 2 (2010), available at $\mathrm{http}: / / \mathrm{www}$.huduser.org/portal/datasets/fmr/fmrover_071707R2.doc.

47. NLIHC, Pittsburgh HMFA, http://www.nlihc.org/oor/oor2009/data.cfm?getstate=on\&getmsa= on\&msa=2279\&state=PA (last visited Feb. 10, 2010).

48. See U.S. Dep't of Hous. \& Urban Dev., supra note 38 and accompanying text.

49. NLIHC, Pittsburgh HMFA, supra note 47.

50. Assuming 40 hours per week, 52 weeks per year.

51. NLIHC, Pittsburgh HMFA, supra note 47.

52. This wage increased to $\$ 7.25$ in July 2009. 34 PA. CODE $§ 231.101$ (2006).

53. NLIHC, Pittsburgh HMFA, supra note 47.

54. See supra note 38.

55. NLIHC, Pittsburgh HMFA, supra note 47.

56. Assuming 40 hours per week, 52 weeks per year.

57. NLIHC, Pittsburgh HMFA, supra note 47.

58. Id. 
In Philadelphia, the Fair Market Rent for a two-bedroom apartment is $\$ 1,005$ per month. ${ }^{59}$ To afford this rent, ${ }^{60}$ a household must earn $\$ 3,350$ monthly or $\$ 40,200$ annually. ${ }^{61}$ Assuming a worker works $2,080^{62}$ hours per year, the housing wage is $\$ 19.33$ per hour worked. ${ }^{63}$ A minimum-wage worker in Pennsylvania earns $\$ 7.15 .{ }^{64}$ For a minimum-wage worker to afford the Fair Market Rental for a two-bedroom apartment, she must work 108 hours a week or be a part of a household that includes 2.7 minimum-wage workers.

\section{The Role of Affordable Housing in a Community}

The lack of affordable housing within a municipality leads to several notable consequences, including the lack of a balanced workforce, the lack of businesses, the lack of economic stimulus, overcrowding of existing housing, the provision of second-rate municipal services to these residents, fewer educational opportunities, and increased unemployment. ${ }^{65}$ As John R. Nolon explains:

There is a close relationship between the public welfare and an adequate stock of affordable housing. Without affordable housing, the balanced work force needed to attract and retain commercial and industrial development will not exist. Without business development, the community will not enjoy the benefits of a diversified tax base. A diversified tax base eases the pressures on residential taxpayers, creates stability for the municipal corporation, and helps the community weather economic changes. The development of affordable housing for the young and old, for people of low and middle income, breathes fairness into the development pattern of a locality, and provides living accommodations for all segments of the population. This diversified housing stock creates a heterogeneous population and economy and an equitable distribution of housing opportunity, thereby furthering the objectives of comprehensive planning. ${ }^{66}$

59. NLIHC, Philadelphia-Camden-Wilmington MSA, http://www.nlihc.org/oor/oor2009/data.cfm ?getmsa $=$ on $\& m s a=2275 \&$ state $=$ PA (last visited Feb. 10, 2010) [hereinafter NLIHC, Philadephia].

60. See supra note 38 .

61. NLIHC, Philadelphia, supra note 59.

62. Assuming 40 hours per week, 52 weeks per year.

63. NLIHC, Philadelphia, supra note 59.

64. $I d$.

65. See Or. Hous. \& Cmty. Servs., Housing as an Economic Stimulus: The Economic And Community Benefits of Affordable Housing Development 5, 21-25 (2005), available at http://www.ohcs.oregon.gov/OHCS/docs/HousingEconomicStimulus.pdf; Jennifer M. Morgan, Comment, Zoning For All: Using Inclusionary Zoning Techniques to Promote Affordable Housing, 44 EMORY L.J. 359, 359-60 (1995); Powell, supra note 44, at 196-97.

66. John R. Nolon, Shattering the Myth of Municipal Impotence: The Authority of Local Government to Create Affordable Housing, 17 Fordham URB. L.J. 383, 384 (1989). 
John A. Powell argues that a lack of affordable housing lessens a community's opportunity to provide access to wealth, employment, transportation, childcare, education, health, and democratic participation. ${ }^{67} \mathrm{In}$ essence, Powell's argument makes access to affordable housing a key requirement for access to these other opportunities. ${ }^{68}$ Describing affordable housing's relationship with employment and transportation, Powell finds that:

[W]here people live in the metropolitan region plays a significant role in their employment prospects .... Because long distances and traveling time restrain the ability of people to gain and keep jobs, people tend to choose housing or to relocate in proximity to employment sites. This is true when there is a choice in housing, but when affordable housing is not present near job growth, this choice dissolves. ${ }^{69}$

This spatial mismatch, in turn, affects the employment and earnings of the affordable housing population. ${ }^{70}$

\section{Economic Impediments to the Construction of Affordable Housing}

Professors Glaeser and Gyourko, writing for the Federal Reserve Bank of New York, respond to the general outcry of an affordable housing crisis by sharply dissecting the issue into two, separate components - the cost of housing and the level of poverty. ${ }^{71}$ This dissection is crucial, according to Glaeser and Gyourko, because a governmental response comprised of increasing housing supply to address the issue of poverty is inapposite and therefore ineffective. ${ }^{72}$ An affordable housing crisis, according to Glaeser and Gyourko, means that the cost of housing is expensive relative to its cost of production; not that people are poor. ${ }^{73}$ Concomitantly, Glaeser and Gyourko argue that the ability to pay for housing is an inaccurate benchmark for measuring affordability. ${ }^{74}$ Instead, the physical construction costs of housing should be used as the benchmark. ${ }^{75}$ Thus, if there is indeed an affordable

67. See Powell, supra note 44, at 195-96.

68. Id.

69. Id. at 196.

70. Id. See also Timothy J. Choppin, Breaking the Exclusionary Land Use Regulation Barrier: Policies to Promote Affordable Housing in the Suburbs, 82 GEO. L.J. 2039, 2044 (1994).

71. Edward L. Glaeser \& Joseph Gyourko, The Impact of Building Restrictions on Housing Affordability, Fed. Reserve Bank of N.Y. Econ. Policy Rev., June 2003, at 21.

72. Id.

73. $I d$.

74. Id.

75. Id. 
housing crisis, the correct response is to increase the supply of housing. As the social cost of constructing this housing cannot be less than the cost of constructing the increase in the supply of housing, increasing the housing supply will ultimately lead to social costs rather than social gains. ${ }^{76}$

Using 2000 Census data and construction cost data from R.S. Means, Glaeser and Gyourko found that generally, the price of existing housing is close to the cost of new construction. ${ }^{77}$ Analyzing housing data from different parts of the United States, Glaeser and Gyourko employed an empirical analysis and concluded that America does not uniformly face an affordable housing crisis. ${ }^{78}$ Instead, as the "housing wage" across the country evidences, America is more likely facing a poverty crises. ${ }^{79}$

Focusing on areas of America facing relatively high housing costs in relation to the cost of new construction, Glaeser and Gyourko examined whether this high relative cost results from the natural inelasticity of land or from an artificial inelasticity placed on the land by land-use regulations. ${ }^{80}$ The results of this analysis clearly suggest that land use regulation is responsible for the high cost of housing relative to the cost of construction where housing costs are high. ${ }^{81}$ These results hold true where the cost of housing is relatively high compared to the cost of new construction, but not in cities such as Pittsburgh where the cost of housing, generally, is significantly less than the cost of new construction. ${ }^{82}$

This research raises two important points that local governments and proponents of government-subsidized affordable housing must recognize. First, most government programs that address the supply of housing will have a social cost, usually measurable as the difference between the market rate of new construction and the selling price of the units. Second, land use regulations do place artificial limitations on the supply of land. As discussed in further detail below, ${ }^{83}$ any type of zoning regulation places artificial limits on the supply of land and thus increases the cost of land. As the cost of land constitutes approximately 20 percent of the cost of housing, the impact of land

\footnotetext{
76. Id.

77. Glaeser \& Gyourko, supra note 71, at 22.

78. Id. at 23 .

79. See Bezdek, supra note 44, at 69 n.157; Powell, supra note 44, at 192. See also supra text accompanying note 44 .

80. Glaeser \& Gyourko, supra note 71 , at 28 .

81. Id. at 35 .

82. Edward L. Glaeser \& Joseph Gyourko, Urban Decline and Durable Housing 4, 46 (HARV. Inst. of Econ. Research, Discussion Paper No. 1931, 2001).

83. Id. See also discussion infra Part E.1.
} 
use regulations on the cost of housing must be considered. ${ }^{84}$ This second point potentially leaves local governments in an uncomfortable position-the solution sought by local governments may, in fact, be the source of the problem.

A corollary concern municipal governments must also be cognizant of is that "[d] evelopers and home buyers unwilling to abide by land use or housing policies in one place will take their development elsewhere." ${ }^{85}$ All of these considerations consequently coalesce to make the resolution to the affordable housing problem, assuming there is one, a much more complicated issue.

\section{E. Legal Mechanisms Available to Provide Affordable Housing}

\section{Exclusionary Zoning}

During the proceedings leading to the initial validation of comprehensive zoning ordinances, both the arguments for and the arguments against allowing local governments to control private development were thoroughly documented. Those arguing against the constitutionality of these ordinances contended that such power, when exercised on residential housing, would lead to local governments classifying "the population and segregat[ing] them according to their income and station in life. ${ }^{186}$ Countering this argument was the position that zoning could and would be used simply as a good housekeeping mechanism-segregating property uses that would have detrimental effects to the community if it was not segregated. ${ }^{87}$ The benefits of such zoning, so the argument goes, include the prevention of conflicting land uses, the protection of property values, and the minimization of problems associated with overcrowding and urbanization. ${ }^{88}$ This practice of excluding land uses from segments of a community is commonly referred to as "exclusionary zoning," and may be driven by a wide range of motives. ${ }^{89}$

84. See Glaeser \& Gyourko, supra note 71, at 22.

85. Myron Orfield, Land Use and Housing Policies to Reduce Concentrated Poverty and Racial Segregation, 33 Fordham Urb. L.J. 877, 931 (2006) (citing James A. Kushner, Smart Growth, New Urbanism and Diversity: Progressive Planning Movements in America and Their Impact on Poor and Minority Ethnic Populations, 21 UCLA J. ENVTL. L. \& PoL'y 45, 53 (2003)).

86. Ambler Realty Co. v. Vill. of Euclid, Ohio, 297 F. 307, 316 (N.D. Ohio 1924), rev'd, 272 U.S. 365 (1926)

87. See 1 James Metzenbaum, The Law of Zoning 9 (2d ed. 1955) (Metzenbaum represented the Village of Euclid in the Supreme Court case upholding the constitutionality of zoning.).

88. Morgan, supra note 65 , at 359 .

89. Local governments may wish to promote development of land uses that have the potential to 
Whatever the local government's motive, such zoning techniques are viewed by some commentators as "the most common legal impediment to affordable housing. ${ }^{, 90}$ Other commentators believe that exclusionary zoning invariably brings with it other detrimental consequences. ${ }^{91}$ Local governments utilize many different mechanisms to effect these land-use exclusions, including "regulations mandating a minimum lot size and minimum house size, large lot-frontage requirements, and limitations or bans on multi-family housing and manufactured housing." ${ }^{92}$ Land use controls such as these, which prescribe "substantial minimum floor area or lot size for residential dwellings," effectively raise the price of residential access to a zone. ${ }^{93}$ These exclusionary regulations are generally implemented through zoning and subdivision controls, as these are the primary land use controls available to exclude unwanted uses. ${ }^{94}$

Challenging these apparently exclusionary ordinances is one legal mechanism through which exclusionary zoning ordinances can be eliminated. Landowners may challenge such ordinances either through state and local courts or through the curative amendment process. The Pennsylvania Supreme Court most recently spoke about court challenges to exclusionary zoning in Township of Exeter v. Zoning Hearing Board. ${ }^{95}$ In analyzing controversies raising objections of exclusionary zoning, Pennsylvania courts begin by first recognizing the competing core interests involved. ${ }^{96}$ These interests include that of (i) a property owner in enjoying her property under the due process provisions of the Fifth and Fourteenth Amendments to the United States Constitution, and (ii) a municipality in placing reasonable limitations on the use of private property through the enactment of zoning ordinances in the

produce high tax revenues [e.g., luxury condominiums] rather than high density, low-cost housing. Other motives, such as the retention of open space, the preservation of property values, or the preservation of the character of neighborhoods also exist. See JUERGENSMEYER \& ROBERTS, supra note 7, at 230.

90. Orfield, supra note 85 , at 888 (noting that when the only type of development permitted is associated with high-cost housing, the "siting and production [of affordable housing] becomes nearly impossible").

91. Exclusion of lower cost housing from a community leads to the higher cost of housing, the promotion of urban sprawl, the increase in costs of providing municipal services, and an increased burden upon the urban poor. See Juergensmeyer \& Roberts, supra note 7, at 230-31.

92. See id. at 231.

93. Lawrence Gene Sager, Tight Little Islands: Exclusionary Zoning, Equal Protection, and the Indigent, 21 STAN. L. REV. 767, 781 (1969).

94. See Juergensmeyer \& Roberts, supra note 7, at 231.

95. Twp. of Exeter v. Zoning Hearing Bd., 962 A.2d 653 (Pa. 2009).

96. Precision Equities, Inc. v. Franklin Park Borough Zoning Hearing Bd., 646 A.2d 756, 759 (Pa. Commw. Ct. 1994). 
exercise of its police power. ${ }^{97}$ Courts then utilize a three-prong test (coined in Surrick v. Zoning Hearing Board ${ }^{98}$ ) for determining whether a zoning ordinance is unconstitutionally exclusionary. ${ }^{99}$ The court, in Precision Equities, explained the operation of the test as follows:

These core principles [private property rights and the municipality's police power] inspired our decisions in a line of cases collectively embracing the following view: Where a municipal subdivision is a logical place for development to occur, it must assume its rightful part of the burdens associated with development, neither isolating itself nor ignoring the housing needs of the larger region. This philosophy finds concrete expression in the "fair share" principle, which this Court has adopted. It requires local political units to "plan for and provide land use regulations which meet the legitimate needs of all categories of people who may desire to live within its boundaries . . .."100 The first two parts raise threshold inquiries focusing on a municipality's propensity for population growth and its capacity to accommodate additional development . . . . If a community is a logical area for development and its present level of development does not preclude further development, then it is necessary to conduct the third inquiry, which focuses on determining the exclusionary impact of the zoning ordinance. ${ }^{101}$

The curative amendment process, an alternative to challenging apparently exclusionary ordinances in state and local courts, allows landowners to challenge local zoning ordinances by filing "curative amendments" directly to the municipality. ${ }^{102}$ The ability to challenge such policies in a municipality's zoning regulations outside of state and local judicial systems serves as a more effective weapon for proponents of affordable housing. ${ }^{103}$

97. Twp. of Exeter, 962 A.2d at 659; see also In re Realen Valley Forge Greenes Assocs., 838 A.2d 718, 727 (Pa. 2003); Hopewell Twp. Bd. of Supervisors v. Golla, 452 A.2d 1337, 1341 (Pa. 1982).

98. Surrick v. Zoning Hearing Bd., 382 A.2d 105 (Pa. 1977).

99. Id. at 110; BAC, Inc. v. Bd. of Supervisors, 633 A.2d 144, 147 (Pa. 1993).

100. Precision Equities, 646 A.2d at 759 (citing BAC, Inc. v. Bd. of Supervisors, 633 A.2d 144 (Pa. 1993). See Surrick, 382 A.2d at 110-11 (Pa. 1977); Twp. of Willistown v. Chesterdale Farms, Inc., 341 A.2d 466 (Pa. 1975); Appeal of Kit-Mar Builders, Inc., 268 A.2d 765 (Pa. 1970); Appeal of Girsh, 263 A.2d 395 (Pa. 1970); Nat'l Land \& Inv. Co. v. Kohn, 215 A.2d 597 (Pa. 1965).

101. See Precision Equities, 646 A.2d at 759; Surrick, 382 A.2d at 110-11.

102. Krystle L. Jackson, Comment, Need for Reform: The Pennsylvania "Curative Amendment" in Light of the National Housing Crisis, 18 WidENER L.J. 937, 937 (2009).

103. Id. at 946 . 


\section{Inclusionary Zoning}

Inclusionary zoning laws, ${ }^{104}$ in contrast to exclusionary zoning laws, intend to affirmatively promote the construction of affordable housing. ${ }^{105} \mathrm{In}$ addition to the creation of affordable housing, commentators laud the several concomitant benefits of inclusionary zoning laws. ${ }^{106}$ A wide array of mechanisms are available under the umbrella-term "inclusionary zoning," including zoning appeals legislation, state regulation of comprehensive planning, incentive zoning, mandatory set-asides, and housing linkage fees. ${ }^{107}$

Massachusetts is a jurisdiction that has implemented zoning appeals legislation. ${ }^{108}$ This legislation simplifies the permitting process. Additionally, it shifts the burden of proof to the municipality denying a permit which would produce affordable housing units and requires it to show that the affordable housing needs of the community are met. ${ }^{109}$ Connecticut also adopted similar zoning-appeals legislation. ${ }^{110}$ Connecticut's legislation is distinguishable from Massachusetts's legislation by its clearly broader implications, as it pertains to both government subsidized and unsubsidized development. ${ }^{111}$

In contrast to requiring only standard, parochial zoning ordinances, a handful of jurisdictions require that local zoning ordinances accord with local comprehensive plans that include affordable housing elements. ${ }^{112}$ The State of Florida, for instance, requires that local comprehensive plans include: at 906 .

104. This is also commonly referred to as "inclusionary-housing laws." See Orfield, supra note 85,

105. See Laura M. Padilla, Reflections On Inclusionary Housing and a Renewed Look at Its Viability, 23 Hofstra L. Rev. 539, 540-41 (1995).

106. Orfield, supra note 85, at 906 (explaining that inclusionary zoning laws can produce housing developments "more acceptable to neighboring residents than traditional subsidized low-income housing developments," the alleviation of economic segregation, and the minimum capital outlays required by local governments).

107. See generally Morgan, supra note 65 , at $369-81$.

108. Mass. Gen. Laws AnN. ch. 40B, $\S 20$ (West 2003).

109. Morgan, supra note 65, at 369-81 (citing Mass. Gen. Laws ANN. ch. 40B, $§ 20$ (West 2003)). See also Emily Fabrycki Reed, Tilting at Windmills: The Massachusetts Low and Moderate Income Housing Act, 4 W. NEw ENG. L. REv. 105, 121 (1981) (critiquing this legislation as being too narrow in that it only applies to government subsidized housing developed by public agencies, limited dividend corporations, or non-profit corporations).

110. Conn. Gen. Stat. §§ 8-30(a), (b) (1991).

111. Id.

112. Cal. Gov't Code $\S 65300$ (West Supp. 2010); Fla. Stat. Ann. $§ 163.3161$ (West 2006); Or. Rev. Stat. § 197.295 (1989); Wash. Rev. Code $§ 36.70$ A.010 (1990). See also Florence W. Roisman, Opening the Suburbs to Racial Integration: Lessons for the 21st Century, 23 W. NEW ENG. L. Rev. 65, 69-70 (2001) (reviewing, inter alia, statutes "requir[ing] municipalities to adopt plans for affordable housing and otherwise to support lower-income housing"). 
[a] housing element consisting of standards, plans, and principles to be followed in ... $[\mathrm{t}]$ he provision of adequate sites for future housing, including affordable workforce housing ..., housing for low-income, very low-income, and moderate-income families, mobile homes, and group home facilities and foster care facilities, with supporting infrastructure and public facilities. ${ }^{113}$

To give this comprehensive planning element some "teeth," the State of Florida requires local comprehensive plans to be reviewed at least once every five years. ${ }^{114}$ If the local comprehensive plan is found to not be in compliance with the elements in the Florida Growth Management Act, state funds can be withheld by the State from projects under the province of the local governments. ${ }^{115}$

One of the most vibrant areas of inclusionary-zoning activity is incentive zoning. This is, perhaps, due to the inclination of local-government officials toward inducing the relinquishment of private property rights rather than taking private property rights. Additionally, the lack of upfront, localgovernment funding for these incentives is extremely attractive to a local official seeking to retain her office. ${ }^{116}$ Moreover, as developers will likely be deterred by the reduced profitability associated with the construction of affordable housing, local governments are forced to offer such incentives to ensure that affordable housing units are in fact produced. ${ }^{117}$

One of several mechanisms that fall under the umbrella of incentive zoning laws is the provision of zoning variances for developers of residential housing. ${ }^{118}$ In exchange for a set-aside of a prescribed percentage of affordable housing units in new development, local governments relax some of the requirements of a zoning regulation to increase the intensity of proposed development above the prescribed standard. ${ }^{119}$ There are two key categories

113. Fla. Stat. AnN. $§ 163.3177(6)(f)$ (West Supp. 2010).

114. See id. $\S 163.3191$.

115. Id. $\S 163.3184(11)(\mathrm{a})$.

116. Morgan, supra note 65 , at 378.

117. Orfield, supra note 85 , at 906.

118. See generally Nolon, supra note 66, at 392-93; Orfield, supra note 85, at 906 (stating that "[o]ther statutory development incentives include local tax abatements, waivers of permit fees, reductions in the amenities required to be provided by developers, and government provision or subsidization of infrastructure in support of development").

119. See Powell, supra note 44, at 205-06 (discussing the success of the Moderately Priced Dwelling Unit Program in Montgomery County, Maryland which has produced over 10,000 units of affordable housing from 1996 to 2003). 
of zoning variances used for the construction of affordable housing, namely conditional rezoning of individual parcels and generic zoning. ${ }^{120}$

Conditional rezoning of individual parcels, in the context of creating affordable housing, usually arises when a developer seeks to increase the permitted zoning density of a particular parcel of land. ${ }^{121}$ By conditioning an increase in allowable development density on the concession of a developer to construct units of affordable housing, local governments must be prepared to meet the stringent requirements of the Supreme Court's "nexus" jurisprudence. ${ }^{122}$ According to John R. Nolon, at least, "[w]hen the local government, which could deny the request for rezoning, conditions the rezoning on the provision of some affordable housing for the specific purpose of furthering the comprehensive plan, the constitutionally required 'nexus' between the condition imposed and the burden created by the development is found." $" 123$

Generic zoning for affordable housing offers two alternatives to the conditional zoning of individual parcels, namely special-use permits and floating zones. ${ }^{124}$ A special-use permit has been used successfully in several jurisdictions to permit greater density of development as a bonus to a developer constructing affordable housing units for the elderly. ${ }^{125}$ As commentators note, it is prudent to attach rent or price controls to these density bonuses to ensure that the housing remains affordable. ${ }^{126}$ One jurisdiction, to ensure this continued affordability, requires rental units to be maintained as affordable for 20 years while requiring price restrictions on owner-occupied units for ten years. ${ }^{127}$ After the initial ten-year period, owneroccupied units can be sold at market rates. ${ }^{128}$ However, half of the profits

120. Nolon, supra note 66, at 390-93.

121. Id. at 390-91.

122. Nollan v. Cal. Coastal Comm'n, 483 U.S. 825, 834 (1987) (citing Agins v. Tiburon, 447 U.S. 255,260 (1980)).

123. Nolon, supra note 66 , at 391 n.27.

124. Robert R. Wright \& Morton Gitelman, Land Use 719 (3d ed. 1982).

125. The New Jersey Supreme Court upheld the application of a special-use permit for the provision of elderly housing. Shepard v. Woodland Twp. Comm'n \& Plan. Bd., 364 A.2d 1005, 1015 (N.J. 1976). Massachusetts's Enabling Act specifically allows for the implementation of special-use permits. See MAss. GEN. Laws ch. 40A, $\S 9$ (1985). The New York courts have upheld the use of special-use permits as being within the bounds of the city's police power. See Asian Ams. for Equality v. Koch, 514 N.Y.S.2d 939 (N.Y. App. Div. 1987), aff'd, 72 N.Y.2d 121 (N.Y. 1988).

126. Robert W. Burchell \& Catherine C. Galley, Inclusionary Zoning: Pros and Cons, New Century Housing, Oct. 2000, http://www.nhc.org/pdf/pub_nc_10_00.pdf. See also Morgan, supra note 65 , at 378 .

127. Brown, supra note 42 , at 5 .

128. Id. at 6. 
earned by the owner-occupier must be remitted to the county's Housing Initiative Fund. ${ }^{129}$ These remitted profits are then used to aid the future development and rehabilitation of affordable housing. ${ }^{130}$

Another mechanism used by local governments from the inclusionaryzoning toolkit is commonly referred to as mandatory set-asides. Essentially, a developer within a jurisdiction with such a mechanism must include a minimum number of affordable housing units within the market-priced housing units. ${ }^{131}$ Implementation of this mechanism raises constitutional concerns, however, as it forces private property owners to develop their property at a price less than what the market will bear. ${ }^{132}$ According to the Court, a land-use regulation "does not effect a taking if it 'substantially advance[s] legitimate state interests' and does not 'den[y] an owner economically viable use of his land." "'133 Justice Scalia, writing for the Court in Nollan v. California Coastal Commission, ${ }^{134}$ expounds on the Court's view regarding mechanisms that condition the approval of proposed development upon an extraction by the local government:

[A] permit condition that serves the same legitimate police-power purpose as a refusal to issue the permit should not be found to be a taking if the refusal to issue the permit would not constitute a taking. . . . [T] he condition would be constitutional even if it consisted of the requirement that the [property owners] provide a viewing spot on their property for passersby with whose sighting of the ocean their new house would interfere $\ldots$

The evident constitutional propriety disappears, however, if the condition substituted for the prohibition utterly fails to further the end advanced as the justification for the prohibition. When that essential nexus is eliminated, the situation becomes the same as if [the] law forbade shouting fire in a crowded theater, but granted dispensations to those willing to contribute $\$ 100$ to the state treasury ... . The purpose then becomes, quite simply, the obtaining of an easement to serve some valid governmental purpose, but without payment of compensation. Whatever may be the outer limits of "legitimate state

\section{Id. at 7 .}

130. $I d$.

131. The "affordability" of a housing unit is generally derived by local governments applying a percentage to the area's median income. See Burchell \& Galley, supra note 126, at 3.

132. See U.S. ConST. amend. V ("Private property [shall not] be taken for public use, without just compensation."). The Fifth Amendment is made applicable to the several states through the Fourteenth Amendment. See U.S. Const. amend. XIV.

133. Nollan v. Cal. Coastal Comm'n, 483 U.S. 825, 834 (1987) (citing Agins v. Tiburon, 447 U.S. 255, 260 (1980)). See also Penn Cent. Transp. Co. v. New York City, 438 U.S. 104, 127 (1978) (holding that "a use restriction may constitute a 'taking' if not reasonably necessary to the effectuation of a substantial government purpose").

134. The California Coastal Commission granted a permit to the Nollans to replace a small bungalow on their beachfront lot with a larger house upon the condition that they allow the public an easement to pass across their beach, which was located between two public beaches. Nollan, 483 U.S. at 825 . 
interests" in the takings and land-use context, this is not one of them. In short, unless the permit condition serves the same governmental purpose as the development ban, the building restriction is not a valid regulation of land use but "an out-and-out plan of extortion." 135

Some commentators have argued that the provision of affordable housing is a legitimate state interest. ${ }^{136}$ Furthermore, as the conditions imposed by mandatory set-aside regulations require the construction of affordable housing units, such mechanisms directly advance this state interest. ${ }^{137}$ Thus, pursuant to the Court's analysis in Nollan, as long as a mandatory set-aside regulation for the construction of affordable housing does not "den[y] an owner economically viable use of his land," such regulation will likely survive constitutional challenge. ${ }^{138}$ To ensure that property owners are not denied this viability, local governments will often provide economically beneficial incentives such as density bonuses. ${ }^{139}$ Providing economically beneficial incentives may shift the character of regulation to feel much more like incentive zoning and in turn improve the regulation's chance of surviving legal challenges. ${ }^{140}$ The Moderately Priced Dwelling Unit Ordinance, adopted in 1973 by Montgomery County, Maryland, is an example of a mandatory setaside ordinance that provides economic incentive to developers in exchange for the construction of a set percentage of affordable housing units. ${ }^{141}$ The longevity and success of this program is well documented. ${ }^{142}$

Still another mechanism used by local governments to generate affordable housing is the application of "linkage fees" on commercial or market-rate residential development. ${ }^{143}$ The proceeds of these fees are used to fund the construction of affordable housing. The rationale for applying these fees to

135. Id. at 836-37.

136. Nolon, supra note 66, at 384. See generally Marc T. Smith \& Ruth L. Steiner, Affordable Housing as an Adequate Public Facility, 36 VAL. U. L. Rev. 443, 445 (2002); Serena M. Williams, The Need for Affordable Housing: The Constitutional Viability of Inclusionary Zoning, 26 J. MARSHALL L. REV. 75, 101-03 (1992).

137. Morgan, supra note 65 , at 380

138. Nollan, 483 U.S. at 834 (citing Agins, 447 U.S. at 260).

139. Brown, supra note 42 , at 6-7 (explaining that the MDPU program requires that any new housing development of fifty or more units set aside twelve and one-half to fifteen percent of the units for households earning sixty-five percent or less of the area's median income. As compensation for building the mandated MPDUs, developers can receive a density bonus of up to twenty-two percent.).

140. This substantive change is likely beneficial for the survival of the regulation, as courts are much more friendly to incentive zoning regulations than mandatory set-asides. See David J. Barron, Reclaiming Home Rule, 116 HARV. L. REv. 2255, 2357 (2003).

141. See Nolon, supra note 66 , at 384

142. See Roisman, supra note 112, at 94-95. See also Brown, supra note 42, at 5.

143. See Powell, supra note 44, at 206-07. 
commercial development is that as commercial development creates jobs, it also creates a need for affordable housing units. ${ }^{144}$ The rationale for applying these fees to market-rate residential development is that such development will potentially displace affordable units, and the fees are required to mitigate this effect. ${ }^{145}$ Some commentators have even argued for treating affordable housing as an element of a municipality's infrastructure and therefore subject to the jurisdiction's concurrency requirements. ${ }^{146}$

\section{Creating Affordable Housing in Pennsylvania}

\section{A. Pennsylvania Land Use Authority}

As discussed above, the authority to manage the placement and timing of physical development within a community has been repeatedly held as a proper exercise of a state's police power. ${ }^{147}$ Historically, local governments, acting as municipal corporations, were treated as "creatures of the state" to limit their power of initiative and assert the state's legislative preemptive power. ${ }^{148}$ Dillon's Rule, as adopted by the U.S. Supreme Court, ${ }^{149}$ is a nineteenth century judicial rule of interpretation for decisions pertaining to municipal governance that encapsulates this understanding of the role of local government. ${ }^{150}$ Acknowledging that the incorporation of the municipality impliedly provided some power (i.e., the power to administer local affairs), the formulation of Dillon's rule ensured that local governments did not exercise authority beyond those powers. ${ }^{151}$ As stated, Dillon's Rule ensured that local governments only exercised those powers that could be traced to express delegations from the state. ${ }^{152}$ Using this construct, Pennsylvania's General Assembly has expressly delegated to the vast majority of local

144. Id. at 207.

145. $I d$.

146. See Smith \& Steiner, supra note 136, at 444 (arguing that under Florida's concurrency requirements a local government would (i) be able to prohibit development in certain areas, (ii) be required to provide the infrastructure, (iii) or be able to require the developer to "bar the cost of solving the inadequacy").

147. See Reinman v. Little Rock, 237 U.S. 171, 176-77 (1915).

148. Barron, supra note 140, at 2280-81,2285 (noting a commentator's opinion that the impetus for treating municipal corporations as merely "creatures of the state" likely arose from a fear that local governments would shed their "anti-redistributive local past" for a "threatening, redistributive future").

149. Hunter v. Pittsburgh, 207 U.S. 161, 177 (1907).

150. Barron, supra note 140, at 2285.

151. $I d$.

152. 1 John F. Dillon, Law of Mun. Corporations $\S 237(89)$ (5th ed. 1911). 
governments primary land use control. ${ }^{153}$ The two notable exceptions to this grant, discussed below, are the City of Pittsburgh and the City of Philadelphia.

Beginning in the late nineteenth century, a movement emerged to challenge the "creature of the state" vision for local governments that Dillon's Rule sought to perpetuate. ${ }^{154}$ This movement, known generally as the "Home Rule" movement, was motivated by distrust of the state government to handle local affairs. ${ }^{155}$ Supporters of home rule sought the adoption of a more liberal view of delegated powers, and a "grant [of] authority to municipalities, through municipal charters, to enact measures necessary to promote the "general welfare." 156 According to one commentator, "[h]ome rule means shifting responsibility for local governance from the State Legislature to the local community ... . [A home rule charter] is a body of law, a framework within which the local governing body can adopt, adapt and administer legislation and regulations for the conduct of business, expansion of citizen participation in decision-making and creation of sustainable communities." ${ }^{157}$

The history of home rule in Pennsylvania began in 1922 when the Pennsylvania Constitution was amended to allow the Legislature to grant cities the right to adopt home rule charters. ${ }^{158}$ In 1949, when the General Assembly finally took action on this constitutional amendment, only the City of Philadelphia was authorized to adopt such a charter. ${ }^{159}$ The option for home rule was presented to the rest of Pennsylvania municipalities during the Constitutional Convention of 1968-1969. ${ }^{160}$ Four years later, the General Assembly passed the Home Rule Charter and Optional Plans Law, fulfilling the constitutional mandate. ${ }^{161}$ The residents of the City of Pittsburgh decided to exercise this grant of authority by adopting a home rule charter. ${ }^{162}$ $\S 10105$.

153. Cf. Pennsylvania Muns. Plan, Code, 53 Pa. Stat. Ann. pmbl. (2005); 53 Pa. Stat. Ann.

154. Barron, supra note 140 , at 2292-93.

155. William D. Valente \& David J. McCarthy, JR., Local Government law 63 (4th ed. 1992).

156. Joel P. Dennison, Comment, New Tricks for an Old Dog: The Changing Role of the Comprehensive Plan Under Pennsylvania's “Growing Smarter" Land Use Reforms, 105 Dick. L. Rev. 385, 418 n.30 (2001) (citing VALENTE \& MCCARTHY, supra note 155, at 63-64).

157. Cmty. Envtl. Legal Def. Fund, Home Rule for Pennsylvania, http://www.celdf.org/HomeRule/ PennsylvaniaandHomeRule/tabid/116/Default.aspx (last visited Feb. 10, 2010).

158. Id.

159. $I d$.

160. $I d$.

161. Id.

162. 302 Pa. CodE $\S \S 11.1-101$ to 11.8-813 (2009). See also Klein v. Council of Pittsburgh, 643 A.2d 1107, 1109 (Pa. Commw. Ct. 1994); Pessolano v. Zoning Bd. of Adjustment, 632 A.2d 1090, 1093 n.3 (Pa. Commw. Ct. 1993); Sorbara v. City of Pittsburgh, 471 A.2d 927, 928 (Pa. Commw. Ct. 1984); 
Although the City of Pittsburgh is a home rule municipality within the protection of Pennsylvania's Home Rule Charter and Optional Plans Law, the City has limited home rule derived power to regulate the placement or timing of land development. ${ }^{163}$ The Home Rule Charter and Optional Plans Law specifically curtail the powers of municipal governments to regulate the development of land to those contained in the Municipalities Planning Code of 1968 - the express delegation of primary land-use control. ${ }^{164}$ As the City of Pittsburgh is, in turn, not subject to the Municipalities Planning Code due to its status as a city of the second class, ${ }^{165}$ the City must derive its land-use regulatory authority from its "original enabling legislation and any subsequent statutes applying to second class cities in particular or to municipalities in general and not in the MPC."166 Thus, the City derives its zoning authority from Act No. 69 of 1927, its subdivision control from sections 9 through 12 of a separate 1927 Act, and its authority to adopt an official map from sections 5 through 8 and 14 through 20 of the same, separate Act. ${ }^{167}$ Consequently, the City of Pittsburgh can still be categorized as a "creature of the state" and therefore must derive its land use authority from the second-class city enabling act.

Philadelphia, on the other hand, has a Home Rule Charter (the "Charter") that gives the City "all powers and authority of local self-government" and "complete powers of legislation and administration in relation to its municipal functions," as well as "the power to enact ordinances and to make rules and

Tuckfelt v. Zoning Bd. of Adjustment, 471 A.2d 1311, 1313 (Pa. Commw. Ct. 1984).

163. Cyril A. Fox, Land-Use Controls for Hillside Preservation in the City of Pittsburgh 1 (2004), available at http://www.alleghenylandtrust.org/special_projects/hillsides/pdf/ 198605LegalReport20041130.pdf.

164. 53 Pa. Cons. Stat. § 2962(a)(10) (2006) (“(a) Powers granted by statute.-With respect to the following subjects, the home rule charter shall not give any power or authority to the municipality contrary to or in limitation or enlargement of powers granted by statutes which are applicable to a class or classes of municipalities: ... (10) Municipal planning under the act of July 31, 1968 (P.L. 805, No. 247), known as the Pennsylvania Municipalities Planning Code"). See also Delaware County v. Middletown Twp., 511 A.2d 811, 813-14 (Pa. 1986).

165. 53 Ра. Stat. Ann. $§ 10107$ (West 2009) (explaining that cities of the first and second class are exempted from the application of the MPC due to their exclusion from the definition of " $[\mathrm{g}]$ overning body").

166. Fox, supra note 163, at 1. See also Vitti v. Zoning Bd. of Adjustment, 710 A.2d 654, 657 n.4 (Pa. Commw. Ct. 1998) (describing variance criteria); Klein, 643 A.2d at 1109-10 (describing conditional use); Pessolano, 632 A.2d at 1093 n.3; Nernberg v. City of Pittsburgh, 620 A.2d 692, 694 n.5 (Pa. Commw. Ct. 1993) (describing standing to appeal grant of conditional use); N. Point Breeze Coal. v. City of Pittsburgh, 431 A.2d 398 (Pa. Commw. Ct., 1981) (describing conditional use).

167. Fox, supra note 163 , at 1 . 
regulations necessary and proper for carrying into execution its powers." ${ }^{168}$ In exercising this general grant of authority, the City is empowered to create and enforce zoning ordinances to provide an orderly method and plan of development. ${ }^{169}$

The result is that Pennsylvania has three separate legislative regimes under which land use controls are adopted. First, the vast majority of municipalities derive their authority from Pennsylvania's Municipalities Planning Code. Second, the City of Pittsburgh derives its authority from the second-class city legislation. ${ }^{170}$ Third, the City of Philadelphia derives its authority from its Charter. ${ }^{171}$ The remainder of this article will attempt to analyze the efficacy of the aforementioned legislative regimes in creating affordable housing in Pennsylvania.

\section{B. Exclusionary Zoning}

As mentioned above, the curative amendment process allows landowners to challenge local zoning ordinances by filing "curative amendments" directly to the municipality rather than substantively challenging the ordinances in state and local courts, ${ }^{172}$ allowing for a more effective weapon for proponents of affordable housing. ${ }^{173}$ As explained in detail, below, only Pennsylvania's Municipalities Planning Code provides for a curative amendment process. Consequently, municipalities operating under this legislative regime are, at least theoretically, in a better position to challenge the deleterious effects of exclusionary zoning on the creation of affordable housing.

\section{Philadelphia's Home Rule Charter}

Section 14-1708 of Philadelphia's Municipal Code provides that the enactment and amendment of zoning ordinances will follow, essentially, the procedures set out in the Charter. The Charter, in turn, provides that " $[\mathrm{t}] \mathrm{he}$ City Planning Commission shall prepare proposed zoning ordinances, which may embody regulations and maps, and amendments thereto, and submit such proposed zoning ordinances and amendments thereto to the Mayor for

168. 351 Pa. Code $\S 1.1-100$ (2010).

169. See id. $\S 2.2-307$.

170. 53 Pa. Cons. STAT. $\S \S 25051-25058$ (2006)

171. Id. §§ 13101-13116.

172. Jackson, supra note 102, at 937.

173. Id. at 946 . 
transmission to the Council." 174 Section 5-1006 of the Charter provides the Zoning Board of Adjustment with the authority to hear and decide (i) appeals in zoning matters, (ii) special exceptions to any zoning ordinance, as well as (iii) variances to any zoning ordinance. ${ }^{175}$

The Charter was adopted in 1951 pursuant to Article IX, Section 2 of the Pennsylvania Constitution ${ }^{176}$ and the enabling First Class City Home Rule Act of 1949. ${ }^{177}$ Pennsylvania's General Assembly, however, retains the power to limit the functions performed by Philadelphia under its Charter. ${ }^{178}$ The General Assembly exercised this power with its recent enactment of Section 17.1 of the First Class City Home Rule Act (the "Home Rule Act"). ${ }^{179}$ This section, among other things, limits parties that are able to appeal the decision of a zoning hearing board or other board or commission created to regulate development within a city to (i) the governing board vested with legislative powers under any charter adopted under the Home Rule Act, and (ii) an "aggrieved person." "180 This restrictive language trumps the broader language within the Charter. ${ }^{181}$ As such, the sole method of amending a zoning ordinance in the City of Philadelphia is for a taxpayer, aggrieved by application of the ordinance, to challenge the ordinance in Pennsylvania's courts.

\section{Second-Class City Legislation}

Pennsylvania's second-class city legislation is contained in Sections 22101 through 28707 of Pennsylvania's Consolidated Statutes. ${ }^{182}$ The portion of this larger legislation of particular relevance to developers of affordable

174. 351 PA. Code $\S 4.4-601$ (2010).

175. Philadelphia, Pa., Home Rule Charter § 5-1006 (2009).

176. Spahn v. Zoning Bd. of Adjustment, 977 A.2d 1132, 1144 n.5 (Pa. 2009) (“[T]he current constitutional provision[,] Article 9, Section 2[,] became the constitutional authority for home rule when a new Pennsylvania Constitution was adopted in 1968. Prior to that time, the relevant provision was Article 15, Section 1, which was adopted in 1922 and was substantively identical to the current provision.”).

177. First Class City Home Rule Act of 1949, 53 Pa. Stat. AnN. § 13101 (2009).

178. "A municipality which has a home rule charter may exercise any power or perform any function not denied by this Constitution, by its home rule charter or by the General Assembly at any time." PA. Const. art. IX, § 2; Spahn, 977 A.2d at 1143-44. See also Ortiz v. Commonwealth, 681 A.2d 152, 156 (Pa. 1996).

179. 53 Pa. Stat. AnN. § 13131.1 (West 2009).

180. "[T] $]$ he term 'aggrieved person' does not include taxpayers of the city that are not detrimentally harmed by the decision of the zoning hearing board or other board or commission created to regulate development." Id.

181. Spahn, 977 A.2d at 1145.

182. 53 PA. Stat. AnN. $\S ~ 22101-28707$ (West 2009). 
housing is contained in Sections 25051 through $25059 .{ }^{183}$ This portion begins with the following general mandate:

For the purpose of promoting health, safety, morals or the general welfare of the community, cities of the second class are hereby empowered to regulate, restrict or determine, the height, number of stories and size of buildings and other structures, the percentage of lot that may be built upon, the size of yards, courts and other open spaces, the density of population, and the location, use and occupancy of buildings, structures and land for trade, industry, residence or other purposes. ${ }^{184}$

To effect this general mandate, cities of the second class are charged to divide themselves into districts and to regulate within such districts the "erection, construction, reconstruction, alteration, repair, use, or occupancy of buildings, structures, or land." 185 A city planning commission is authorized to recommend ${ }^{186}$ the boundaries of these districts and the regulations ${ }^{187}$ to be enforced within each district. ${ }^{188}$ Ultimately, the council of each second-class city must provide for the manner "in which such regulations and restrictions and the boundaries of such districts shall be determined, established and enforced, and, from time to time, amended, supplemented or changed." 189

Section 25057 provides a properly appointed board of adjustment the authority to, "in appropriate cases and subject to appropriate conditions and safeguards, make special exceptions to the terms of the ordinance, in harmony with its general purpose and intent and in accordance with general or specific rules therein contained." ${ }^{190}$ This board of adjustment is given the power to "hear and decide special exceptions to the terms of the ordinance upon which such board is required to pass under such ordinance." 191 A landowner aggrieved by a zoning ordinance adopted by a second-class city is subject to the exclusive statutory remedy provided for by Pennsylvania's legislature. ${ }^{192}$

183. Id. §§ 25051-25059.

184. Id. $\S 25051$.

185. Id. $\S 25052$.

186. See Gratton v. Conte, 73 A.2d 381, 384 (Pa. 1950) (noting that a second-class city planning commission is merely a recommendatory body regarding zoning, the final authority rests in the city's elective legislative body)

187. Sun Oil Co. v. City of Pittsburgh, 169 A.2d 294, 296 (Pa. 1961) (“To be valid ... [such] zoning [regulations] must bear a reasonable relationship to the protection of the health, safety, morals or general welfare of the public").

188. 53 Pa. Stat. Ann. § 25054 (West 2009).

189. Id. § 25055.

190. Id. $\S 25057$.

191. $I d$.

192. City of Pittsburgh v. Commonwealth, 400 A.2d 1301, 1302 (Pa. 1979) (citing Pittsburgh Outdoor Adver. v. Clairton, 133 A.2d 542, 546 (Pa. 1957)). 
Specifically, if the board of adjustment finds in favor of the zoning administrator and against a landowner, she must challenge the zoning ordinance in Pennsylvania's courts. ${ }^{193}$ The board of adjustment must abuse its discretion to have its decision overturned. ${ }^{194}$

\section{Pennsylvania Municipalities Planning Code}

In contrast to Philadelphia's Charter and Pennsylvania's second class city legislation, ${ }^{195}$ the MPC provides landowners with a curative amendment process through the following language:

A landowner who desires to challenge on substantive grounds the validity of a zoning ordinance..., which prohibits or restricts the use or development of land in which he has an interest may submit a curative amendment to the governing body with a written request that his challenge and proposed amendment be heard and decided . . . ${ }^{196}$

If the challenge to the current zoning regulation has merit, the governing body may either (i) accept the amendment, with or without revision, or (ii) adopt an alternative amendment fashioned to address the defects of the zoning ordinance being challenged. ${ }^{197}$ Among the several considerations a governing body must take into account in deciding whether to accept a landowner's curative amendment is, "if the proposal is for a residential use, the impact of the proposal upon regional housing needs and the effectiveness of the proposal in providing housing units of a type actually available to and affordable by classes of person otherwise unlawfully excluded by the challenged provision . . . ."198 If the governing body does not find merit in the challenge, the landowner may challenge the zoning ordinance in court. ${ }^{199}$

\section{Zoning Appeals Legislation}

Pennsylvania has not enacted legislation shifting the burden of proof to the municipality denying a permit to show that the affordable housing needs of the community are met. The Pennsylvania Supreme Court, in holding that

193. Id. at $1302-03$.

194. Sun Oil Co. v. City of Pittsburgh, 169 A.2d 294, 298 (Pa. 1961).

195. 53 Pa. Stat. Ann. § 25056 (West 2009).

196. 53 Pa. Cons. Stat. $\S 10609.1$ (a) (2009).

197. Id. § 10609.1(c).

198. $I d$.

199. Id. $\S 10609.1(\mathrm{~b})$. 
the grant of a special exception to a municipality's zoning ordinance was valid, explained the standard for reversal is manifest abuse of discretion or an error of law by the municipality's board of adjustment. ${ }^{200}$ As Pennsylvania's Supreme Court explains in Blair v. Board of Adjustment:

A special exception is issued for an exceptional use which may be permitted within a particular district if the board of adjustment determines its availability. Such uses are made available as a privilege, not as of right, assuming that the requisite facts and conditions detailed in the ordinance are found to exist. Since its allowance is predicated on the exercise of prudent discretion by the Board, only a manifest abuse of that discretion will cause reversal on appeal. ${ }^{201}$

The only significant difference between the denial of a special exception to a municipality's zoning ordinance and the denial of a conditional use is the jurisdiction in which it falls. ${ }^{202}$ As such, Pennsylvania courts treat the grant of a conditional use in much the same way. ${ }^{203}$ As the construction of affordable housing will likely give rise to the need for increased densities, ${ }^{204}$ and in turn give rise to the need for special exceptions and conditional uses, the current state of the law in any of three legislative regimes is not particularly beneficial to the developers of affordable housing.

\section{State Regulation of Comprehensive Planning}

Municipalities with an adopted comprehensive plan and zoning ordinance located within a county with an adopted comprehensive plan have the benefit of Commonwealth agencies considering the documents when reviewing applications for the funding or permitting of municipal infrastructure or other facilities. ${ }^{205}$ Short of this marginal benefit, there is apparently no consequence to not having a comprehensive plan as such. The three legislative regimes, as

200. Jacobi v. Zoning Bd. of Adjustment, 196 A.2d 742, 744 (Pa. 1964) (citing Blair v. Bd. of Adjustment, 169 A.2d 49 (Pa. 1961)).

201. Blair, 169 A.2d at 50 (emphasis in original) (citations omitted).

202. Bailey v. Upper Southampton Twp., 690 A.2d 1324, 1326 (Pa. Commw. Ct. 1997) (footnote omitted) (noting that "a conditional use is nothing more than a special exception which falls within the jurisdiction of the municipal legislative body, rather than the zoning hearing board"). Although the court was speaking in regard to the Municipalities Planning Code, this holds true with respect to Pittsburgh's Municipal Ordinance where it gives the City Council the authority to approve conditional uses. Pittsburgh, Pa. Code $\S 922.06 . E .1$ (2009).

203. See, e.g., Huntley \& Huntley, Inc. v. Borough Council, 929 A.2d 1252, 1255 (Pa. Commw. Ct. 2007) (reversed, in part, on other grounds).

204. See NLIHC, supra note 43 and accompanying text.

205. See Pennsylvania Comprehensive Plan, supra note 17, at 20. 
shown below, do not provide any further incentive to adopt a comprehensive plan.

\section{Philadelphia's Home Rule Charter}

Philadelphia's city council operates under its home rule charter, which vests legislative power of the city exclusively in council and provides it the right to adopt a comprehensive plan relating to zoning within the city. ${ }^{206}$ The First Class City Home Rule Act of 1949 provides that zoning regulations:

[S]hall be made in accordance with a comprehensive plan, and designed to lessen congestion in the streets, to secure safety from fire, panic and other dangers, to promote health and the general welfare, to provide adequate light and air, to prevent the overcrowding of land, to avoid undue concentration of population, to facilitate the adequate provision of transportation, water, sewerage, schools, parks, and other public requirements. Such regulations shall be made with reasonable consideration, among other things, to the topography and character of the district, and its peculiar suitability for particular uses, with a view to conserving the value of buildings and encouraging the most appropriate use of land throughout such city. ${ }^{207}$

Although this legislation mandates the City employ a comprehensive plan, Pennsylvania courts have not required local governments to adopt comprehensives plans, as such, to validate zoning ordinances. ${ }^{208}$ As a result, unless Pennsylvania passes legislation that requires the adoption of a comprehensive plan, as such, this avenue is a dead end to Philadelphia in its efforts to create affordable housing.

\section{Second-Class City Legislation}

Pittsburgh's land use regulations are governed in part by the second class city legislation and in part by home rule principles. ${ }^{209}$ As such, Pennsylvania's second-class city legislation - granting the City of Pittsburgh the power to issue land-use regulations - effectively coexists with Pittsburgh's Municipal Charter. Regardless of this coexistence, the second-class city legislation will

206. Freed v. Power, 139 A.2d 661, 662 (Pa. 1958).

207. 53 Pa. Cons. Stat. $\$ 14754$ (2009).

208. See Donahue v. Zoning Bd. of Adjustment, 194 A.2d 610, 611-12 (Pa. 1963) (holding that the comprehensive plan requirement set forth in Eves v. Zoning Bd. of Adjustment, 164 A.2d 7 (Pa. 1960), did not require a separate comprehensive plan because the zoning ordinance itself could serve as the comprehensive plan).

209. See Fox, supra note 163 and accompanying text. 
be of little help. Although the legislation mandates that the City employ a comprehensive plan, ${ }^{210}$ Pennsylvania courts have not required local governments to adopt comprehensive plans, as such, to validate zoning ordinances. ${ }^{211}$ Thus, unless Pennsylvania's legislature passes legislation that requires the adoption of a comprehensive plan, as such, this technique is of no use to the City of Pittsburgh in the creation of affordable housing.

\section{Pennsylvania Municipalities Planning Code}

The Pennsylvania Municipalities Planning Code deals much more in depth with the requirement of a comprehensive plan, as such. ${ }^{212}$ This legislative regime even requires the inclusion of an element aimed to "meet the housing needs of present residents and of those . . . anticipated to reside in the municipality." 13 This element may include the "accommodation of expected new housing in different dwelling types and at appropriate densities for households of all income levels." 214 This plan must be sent to the governing bodies of contiguous municipalities as well as to the Center for Local Government Services every ten years. ${ }^{215}$ Importantly, the Center for Local Government Services only uses the plan for informational purposes. ${ }^{216}$ This requirement has no teeth. To ensure that the comprehensive plan remains an impotent document, the Municipalities Planning Code provides that no action of the municipality's governing body will be invalid or subject to challenge based upon its inconsistency with such municipality's comprehensive plan. ${ }^{217}$

E. Incentive Zoning, Mandatory Set-Asides, and Housing Linkage Fees

\section{Philadelphia's Home Rule Charter}

Philadelphia's Zoning Code contains an array of incentive zoning provisions, including ordinances aimed at the promotion of development that

210. Pittsburgh, as a city of the second class, shall make land-use regulations "in accordance with a comprehensive plan." 53 PA. Cons. STAT. § 25053 (2009).

211. See Donahue, 194 A.2d at 611-12.

212. 53 Pa. Cons. Stat. $\S 10301-10307$ (2009).

213. Id. § 10301(a)(2.1).

214. Id. (emphasis added).

215. Id. § 10301(c).

216. $I d$.

217. Id. § 10303(c). 
(i) "adheres to pro-environment standards, addresses innovations in transportation and fosters pedestrian and community vitality;" ${ }^{18}$ (ii) provides for public gathering and viewing space, ${ }^{219}$ (iii) provides for mixed-use development, ${ }^{220}$ (iv) protects historically significant areas; ${ }^{221}$ (v) provides for ease of pedestrian travel; ${ }^{222}$ (vi) provides for public restrooms; ${ }^{223}$ and (vii) promotes, albeit indirectly, the development of affordable housing. ${ }^{224}$

\section{Second-Class City Legislation}

Implementation of incentive-zoning policies presents the greatest opportunity for the City of Pittsburgh to aid in the further development of affordable housing. First, under the home rule provisions, Pittsburgh residents can amend the City's charter to include any number of incentives, provided these incentives to not expand the City's authority past the limits set out in the Municipalities Planning Code.

Examples of incentive zoning that are already included in Pittsburgh's Municipal Code include the provision of up to $20 \%$ of additional floor area ratio for developments that include transportation facilities or adequate open space. ${ }^{225}$ Furthermore, the Code includes the opportunity for the transfer of development rights within the downtown zoning district. ${ }^{226}$

\section{Pennsylvania Municipalities Planning Code}

The Pennsylvania Municipalities Planning Code, like Philadelphia's Home Rule Charter and Pennsylvania's Second-Class City legislation, provides for the development and implementation of incentive zoning provisions within a municipalities zoning ordinances. ${ }^{227}$

218. Philadelphia, Pa., Code $\S 14-1633(7)$ (2009).

219. Id. $\S \S 14-1637(20)(\mathrm{b}), 14-214(10)(\mathrm{b})(.1)$.

220. Id. § 14-1637(20)(c).

221. Id. $\S \S 14-214(10),(10)(\mathrm{c})$.

222. Id. § 14-214(10)(b)(.2).

223. Id. § 14-214(10)(b)(.7).

224. Philadelphia, Pa., Code $\S 14-214(10)$ (d) (2009).

225. Pittsburgh, Pa., Code $\S 910.01 . C .4$ (2009).

226. Id. § 910.01.D.1.

227. See, e.g., 53 PA. Cons. STAT. § 10605(3) (2009) (providing increased density within established zones for "the purpose of encouraging innovation and the promotion of flexibility, economy and ingenuity in development, ... and for the purpose of authorizing increases in the permissible density of population or intensity of a particular use based upon express standards and criteria set forth in the zoning ordinance"); id. $\S 10619.1$ (a) (creating, "as a separate estate in land, the development rights therein, and the same are 


\section{CONCLUSION}

It is unclear whether America generally, and Pennsylvania in particular, has an affordable housing problem or a poverty problem. It is fairly clear, however, that the City of Philadelphia, the City of Pittsburgh, and all municipalities operating under Pennsylvania's Municipalities Planning Code currently have the authority to induce the construction of affordable housing through inclusionary zoning policies such as incentive zoning, mandatory setasides, and housing linkage fees. It is also fairly clear that residents of the City of Pittsburgh and the City of Philadelphia are at a disadvantage to municipalities operating under Pennsylvania Municipalities Planning Code when it comes to challenging exclusionary zoning ordinances.

declared to be severable and separately conveyable from the estate in fee simple to which they are applicable"); id. § 10705(d) (providing for the standards of planned residential developments to "vary the density or intensity of land use, otherwise applicable to the land under the provisions of a zoning ordinance of the municipality within the planned residential development in consideration of . . . (3) the location, design, type and use of structures proposed"). 